\title{
Acclimatization and Feeding of Zoea Larvae of Mud Crab Potamon Ebonyicum (Crustacea: Decapoda: Potamidae) in South-East Nigeria
}

\author{
Rupert C. Akpaniteaku \\ Department of Biological Science, Evangel University Akaeze, P.M.B. 129 Abakaliki, Ebonyi State, Nigeria \\ *Corresponding Author: Rupert C. Akpaniteaku, Department of Biological Science, Evangel University \\ Akaeze, P.m.B. 129 Abakaliki, Ebonyi State Nigeria
}

\begin{abstract}
Researches on aspect of biology and cultivability of recently quoted mud crab species (Potamon ebonyicum) have been conducted earlier with the aim to enhance population through aquaculture. The need to ensure availability of dependable seed stock has necessitated research into early stages of the crab species. Studies were therefore carried out to determine larval behavior and response to feeding in captivity. Zoea larvae from the wild were acclimatized for 15 days and fed with two types of feed (cat fish feed and decapsulated artemia) for 21 days. Mortality rate was significantly $(P<0.05)$ high during the period. Population was reduced by $70 \%$ before the feeding commenced. Moulting of carapace was recorded more (4 No) in the group fed with fish feed than in the one fed with artemia (2 No.). Survival rate of larvae fed with artemia was higher (80\%) than those fed with fish feed (40\%). Weight gain was insignificant in the two treatments. Growth rate was higher in the larvae fed with artemia (mean 0.5mm) than in those ones fed with fish feed (mean 0.3mm). Judging by the rate of survival during acclimatization, cannibalism could be a major threat to larval culture. Subsequent investigation with combined feed might yield better results.
\end{abstract}

Keywords: Mud crab; Potamon ebonyicum; Zoea larva; Acclimatize; Feed response.

\section{INTRODUCTION}

Maturation of mud crab is a step wise process apparently passing through physiological maturation before reaching functional adult stage. Mud crab begins life as a larva which hatches from an egg with undeveloped limbs (Fisheries Fact Sheet, 2013) ${ }^{[1]}$. They have been described earlier as feeding on algae, decaying wood and bamboo sticks. As omnivores, they scavenge throughout their local range for wide range of food sources (FAO, 2011 and La Sara et al., 2007) ${ }^{[2,3]}$. Longevity of the larval stage is temperature dependent, with survival rate linked to both temperature and salinity (FAO, $2011)^{[2]}$. Fishing efforts in combination with pollution of habitat by agricultural waste water, and runoff from farming communities and urbanized area, affect population of local stock (Meynecke and Richards, 2014) ${ }^{[4]}$. Pioneering research has been conducted on Potamon ebonyicum. Aspects of biology and cultivation of the mud crab species have been investigated (Akpaniteaku, 2013, 2014, 2015, and Akpanitaeku and Onyemara, 2016) ${ }^{[5-8]}$.

Mud crab fishery is at its early stage of development, and seed stock for most crab farms is harvested from the wild (SPC, 2011) ${ }^{[9]}$. There was need to research into seed stock of the locally available species for possible adaptation of results in the farm. SPC $(2011)^{[9]}$ observed that after going through the larval stage, they appeared to have robust health, and survival through grow out was relatively high. This research was therefore aimed at studying the behavior, feeding response and growth performance of P.ebonyicum in captivity.

\section{Materials ANd Method}

Specimens of male and female P. ebonyicum numbering 20 were captured by methods of Akpaniteaku (2013) ${ }^{[5]}$ from adjacent farming area along Okpurukpu stream (tributary of Ebonyi River) in May 2017. Catch were separated into sexes and nursing mother with active zoeae was randomly selected for the experiment. The zoeae were allowed to stay with their mother in dry receptacle for 24 hours before separation. Active zoea larvae numbering 51 were stocked in 7.0 liter 
Acclimatization and Feeding of Zoea Larvae of Mud Crab Potamon Ebonyicum (Crustacea: Decapoda: Potamidae) in South-East Nigeria

calibrated plastic bucket with water depth of $5.0 \mathrm{~cm}$. They were deliberately transported for 2 hours to experimental station. The survivors ( 32 No) were weighed with $G \&$ G electronic scale to the nearest $0.01 \mathrm{~g}$, and size measurement obtained with flexible butterfly brand, millimeter-calibrated rule.

They were kept in millennium 013 ( 7.0 liter) plastic bowls for 2 weeks, and prevented from escape for 3 days using nylon mosquito net. Temperature of the water was measured with mercury-in-glass thermometer. Feeding was alternated with catfish feed $(0.5 \mathrm{~mm})$ and decapsulated artemia (Tables 1 and 2). The feeds were products of coppens International, Nettetel Germany and Wudi Fengti Aquaculture Company China respectively. Feed was sparingly broadcast on the water once a day between 6.00 and $8.00 \mathrm{pm}$ during the period.

Table I: Nutrient Analysis of the catfish feed (Coppens)

\begin{tabular}{|l|l|}
\hline \multicolumn{1}{|c|}{ Nutrient } & \\
\hline Crude protein & 49.0 \\
\hline Crude fat & 13.0 \\
\hline Crude fiber & 0.8 \\
\hline Crude ash & 8.3 \\
\hline Phosphorus & 1.3 \\
\hline Calcium & 1.8 \\
\hline Sodium & 0.3 \\
\hline Vitamin & Quantity \\
\hline Vitamin A & $100001 \mu \mathrm{kg}^{-1}$ \\
\hline Vitamin C & $150 \mathrm{mgkg}^{-1}$ \\
\hline Vitamin E & $200 \mathrm{mgkg}^{-1}$ \\
\hline Vitamin D3 & $19031 \mu \mathrm{kg}^{-1}$ \\
\hline
\end{tabular}

Source: Coppens International Nettetel Germany (Undated)

Table 2: Nutrient analysis of the decapsulated artemia

\begin{tabular}{|l|l|}
\hline \multicolumn{1}{|c|}{ Nutrient } & \multicolumn{1}{c|}{ Percentage } \\
\hline Protein & 58.0 \\
\hline Ash & 5.8 \\
\hline Moisture & 6.0 \\
\hline Fiber & 2.2 \\
\hline Fat & 16.0 \\
\hline
\end{tabular}

Source: Wudi Fengti Aquaculture Company China (Undated)

Water in the receptacle was changed every other day beginning from the $3^{\text {rd }}$ day in captivity. The larvae were counted during water renewal and number recorded. After 15days they were weighed, counted and randomly divided into two equal treatments.

Treatment I: Fed with the catfish feed

Treatment II: Fed with the decapsulated artemia

The circular millennium plastic basin (7.0 liter) made in Nigeria was used for the experiment. Mean weight of the larvae at stocking was $0.073 \mathrm{~g}$. Feed was given once a day at $5 \%$ body weight between 6.00 and $8.00 \mathrm{pm}$. They were counted every week ( 7 days) and final weight was obtained after 3 weeks (21 days). Data were generated and statically analyzed. The survival variable was analyzed to establish relationship at 5\% significant level.

\section{Results}

\subsection{Observation}

The zoea larvae were crawling in and around pouch when the female was caught. They clung together and formed "zoea bulb" immediately after being separated from their mother. They separated intermittently on their own forming 2 or 3 temporary colonies. The larvae formed a temporary colony each time the receptacle was shaken. They remained in the bulbous colony during transportation to the experimental station. Pieces of meat were observed after separating individuals from the colony. There was visible decline in population after each formation was dispersed. Many of the larvae 
attempted to escape during the first 3 days in captivity. The legs could hold on to the surface of the plastic receptacle. The struggle for escape reduced drastically from the $4^{\text {th }}$ day in captivity. From the $7^{\text {th }}$ day, they would sometime crawl out of water hanging on the surface of the receptacle, and quickly crawl back to water by external stimulus. Escapee was sighted in the night on the $11^{\text {th }}$ day, crawling back to the position of the experimental container. At this stage of development (size $0.5 \mathrm{~mm}$ and weight $0.074 \mathrm{~g}$ ) abdominal features could be seen with the aid of lens, but it was difficult to differentiate female from the male. The larvae in treatment II quickly crawled around in the receptacle each time they were fed with the decapsulated artemia.

\subsection{Moulting}

Moulting of carapace by the larvae during the investigation is presented in Fig I. The larvae moulted more carapaces in treatment I than in Treatment II. Milky white shell was first recorded in T II after 2 days. The second shell was recorded in TI after 7 days. The remaining larvae moulted their carapace at different time during the period. The moulting was recorded during the full moon in June 2017.

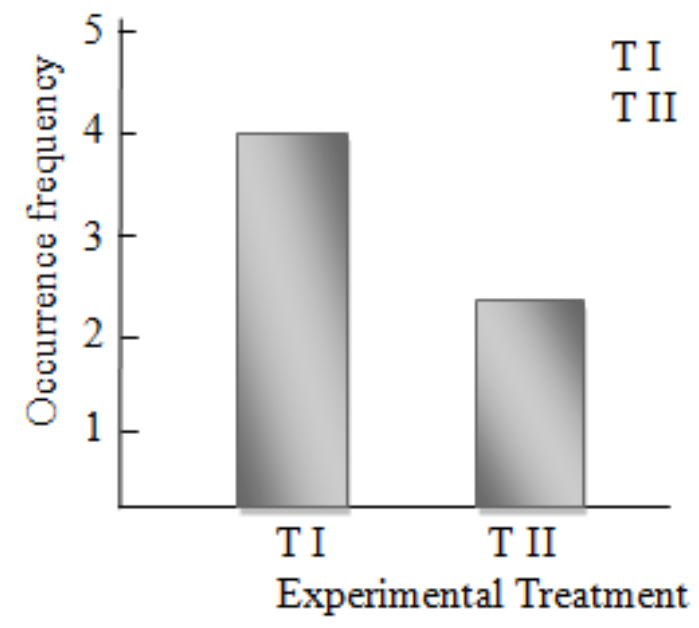

Fig I: Moulting of carapace in zoea larvae of Potamon ebonyicum fed with catfish feed and decapsulated artemia for 21 days

\subsection{Survival}

Population of the larvae decreased as they were separated from the colony, until it came down to $29.41 \%$ after acclimatization (Fig. 2)

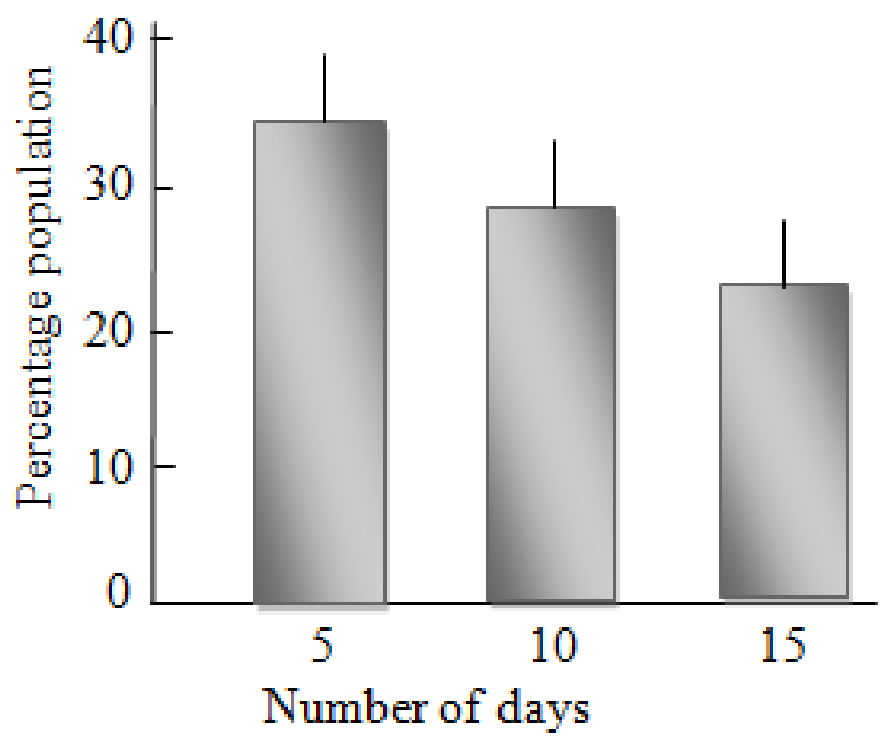

Fig2: Survival rate of larvae of Potamon ebonyicum alternately fed with catfish feed and decapsulated artemia for 15 days. 
The survival rate of the larvae is presented in Fig 3. More casualties were recorded in a few days after stocking than the rest of the experimental period. Casualty was recorded in the two treatments, but there was a poor correlation $(r=0.3)$ in the rate of survival, which was significantly $(P \leq 0.05)$ higher in T II than in T I. The survival rate in T II was $80 \%$ while that of the T I was $40 \%$.

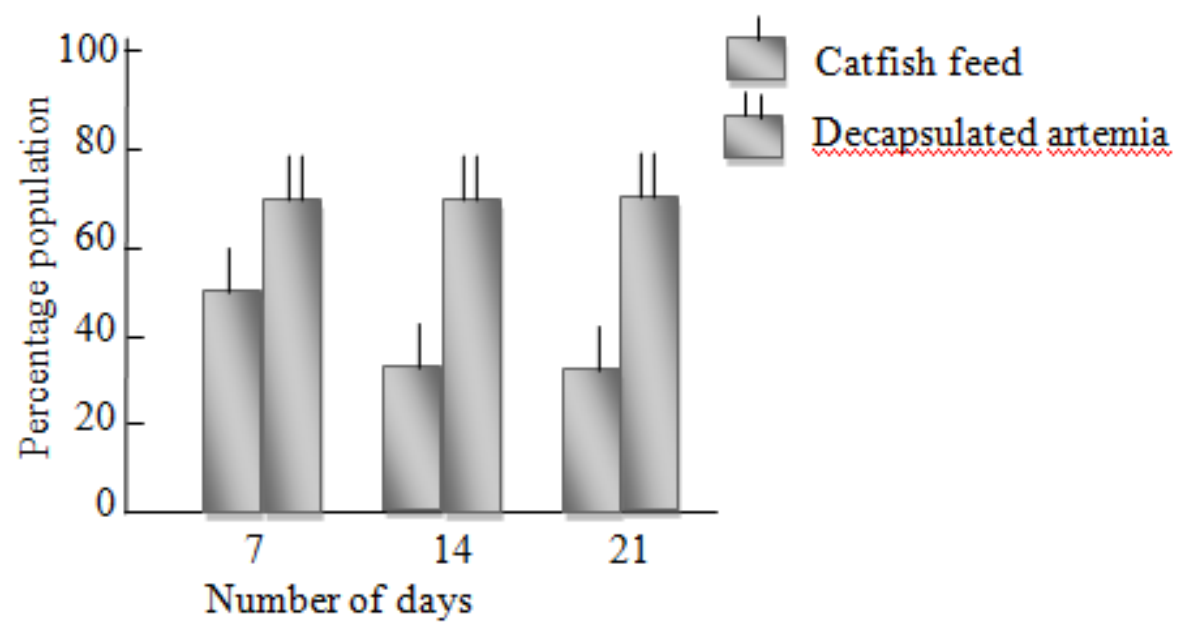

Fig3: Survival rate of larvae of Potamon ebonyicum fed with catfish feed and decapsulated artemia for 21 days

\subsection{Growth}

There was insignificant $(\mathrm{P} \leq 0.05)$ increment in the weights of the larvae during the period (Fig 4). Weight of the larvae fed with catfish feed (T I) was higher (0.09) than that of the larvae fed with decapsulated artemia (T II) $(0.08 \mathrm{~g})$. Weight gain was significantly $(\mathrm{P} \leq 0.05)$ lower in the T II than in the T I.

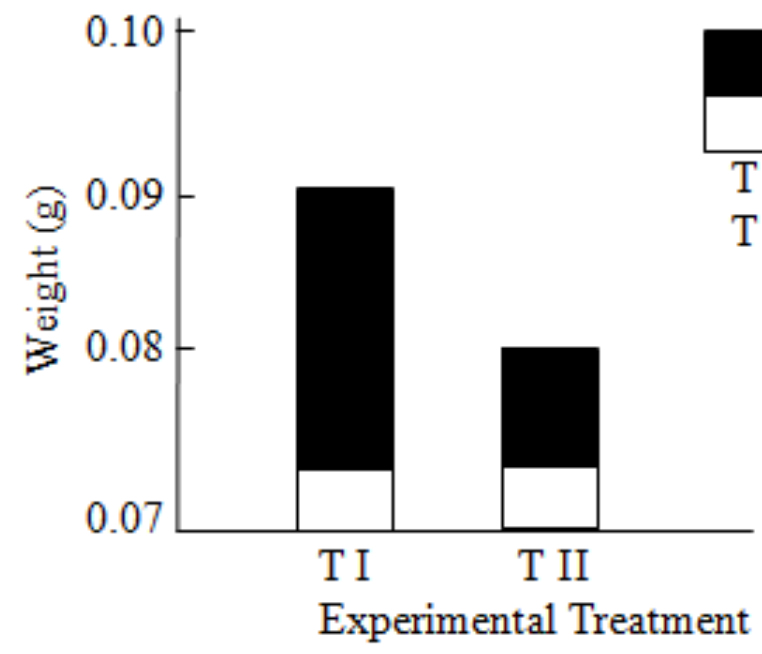

Fig4: Weight of larvae of Potamon ebonyicum fed with catfish feed and decapsulated artemia for 21 days.

Growth rate also was not significant $(\mathrm{P} \geq 0.05)$ in the two groups of larvae (Table 3). Carapace width gained by the larvae fed with decapsulated artemia $(0.5 \mathrm{~mm})$ was more than that of the larvae fed with catfish feed $(0.03 \mathrm{~mm})$.

Table3: Growth Performance of larvae of Potamon ebonyicum fed with catfish feed and decapsulated artemia for 21 days.

\begin{tabular}{|l|l|l|}
\hline \multirow{2}{*}{ Parameter } & Experimental Treatment \\
\cline { 2 - 3 } & T I (Catfish feed) & T II (Decapsulated artemia) \\
\hline Initial carapace width $\mathrm{mmcrab}^{-1}$ & 5.0 & 5.3 \\
\hline Final carapace width $\mathrm{mmcrab}^{-1}$ & 5.3 & 5.8 \\
\hline Daily gain (cw) $\mathrm{mmcrab}^{-1}$ & 0.01 & 0.02 \\
\hline
\end{tabular}


$\mathrm{T} \mathrm{I}=$ Treatment I

$\mathrm{T}$ II $=$ Treatment II
$\mathrm{CW}=$ Carapace width

$\mathrm{mmcrab}^{-1}=$ millimeter per crab

\section{DISCUSSION}

FAO (2011) ${ }^{[2]}$ reported that crabs of various sizes and sex exhibit different responses to stimuli. Agitation of water during transportation may probably be responsible for clinging together and forming of bulbous colony. SPC (2011) ${ }^{[9]}$ reported that they are easily transported either as larvae in water or dry once they have reached the crab stage. Formation of colony in the present investigation may seem to be a protective mechanism. The decline in population after dispersal may possibly suggest that cannibalism was associated with the behavior. FAO $(2011)^{[2]}$ reported that cannibalism at anything other than lower density was a behavior yet poorly understood but presents a major problem for crab aquaculture. This behavior as observed in the present investigation may seem to pose a threat to handling and transportation of the seed stock. Anon (2013) ${ }^{[10]}$ reported that loss during culture could be mainly due to cannibalism and escape of crab. Smooth-surfaced receptacle was early recommended for their culture (Akpaniteaku, 2013) ${ }^{[5]}$. Many larvae attempted to escape during acclimatization despite the smooth nature of the receptacles. Perhaps tip of the legs (dactyl) of the zoea larvae was so rough as to enable them grip the plastic surface. According to Fisheries Fact Sheet $(2013)^{[1]}$ dactyls are covered in tiny hairs that are highly sensitive to touch and taste. Crawling in and out of water without struggling to escape as recorded from the $7^{\text {th }}$ day in captivity, may possibly suggest that period was enough for acclimatizing seeds stock from the wild.

Shedding of shell (moulting) (Fig I) was first recorded 17 days after separation from the parent (Pers. obs.). Antharjanam (2013) ${ }^{[11]}$ reported that after hatching out as zoea, crab larva metamorphose five times into megalopa. Moulting of carapace during the full moon as in the present investigation may seem to be in agreement with increase in gravitational pull observed during full moon, which directly influences the crab (Martins, Pers. comm.). According to Blue Crab Archives (undated) ${ }^{[12]}$, food availability has a major effect on moulting in the summer months. In the present investigation, moulting cycle began in the month of June (Pers. obs.). If a crab does not satisfy the physiological need such as increased muscle tissue, body cavity cramping and so on, it will not enter moulting cycle ( Blue crab Archives, undated) ${ }^{[12]}$. Some of the larvae in the present investigation did not shed their shells probably because of genetic factor or inadequate nutrient to satisfy physiological activity. Fisheries fact sheet $(2013)^{[1]}$ reported that feeding depended on temperature and physiological factors such as if they are moulting. Feeding response was not as good in the present investigation as some of the larvae ran around especially when they were fed with the decapsulated artemia (Pers. obs.). This behavior may seem not to be clearly understood. According to Epelbaum and Borisov (2006) ${ }^{[13]}$, they do not show true hunting behavior but rely on encounter feeding mechanism.

The decline in the population of larvae after separation from temporary colony during the acclimatization (Fig. 2) may seem to expose cannibalistic trait. Epelbaum and Borisov (2006) ${ }^{[13]}$ reported that zoeae are able to capture and ingest wide range of particle size from $100 \mu \mathrm{m}$ to $2 \mathrm{~mm}$, and are highly cannibalistic. The survival rate of larvae (Fig. 3) in the present investigation is such low that cannibalism may seem to be implicated. Baylon (2009) ${ }^{[14]}$ reported that larvae fed purely with artemia nauplii had low survival to megalopa stage. Casualties were recorded more in the group fed with catfish feed than in the one fed with decapsulated artemia (Fig 3.) probably because of the effects of the moulting process. FAO $(2011)^{[2]}$ reported that influence of moulting and injury on juvenile mud crab behaviour failed to find significant links, even though crabs of various sizes exhibit different responses to stimuli $(\mathrm{FAO}, 2011)^{[2]}$. Temperature of $30^{\circ} \mathrm{c}$ (mean) was recorded during the investigation, but ambient temperature of $29-30^{\circ} \mathrm{c}$ was recommended for mud crab development (Anon, 2000) ${ }^{[15]}$. Growth rates of the larvae (Table 3) seem to be in agreement with relatively low rate of growth in the adult crabs (Akpaniteaku, 2013) ${ }^{[5]}$. Growth of adult P. ebonyicum was relatively slow, and that of males with higher initial weight than the females was lower than those of the females (Akpaniteaku, 2013) ${ }^{[5]}$. Sexes were not separated in the present investigation as abdominal features could not be seen properly at this stage (Pers. obs.). According to Anon $(2000)^{[15]}$, zoea larva in the initial stage could measure about $1.0 \mathrm{~mm}$, but terminal size of larva in the present investigation was $5.5 \mathrm{~mm}$ (Table 3). Quinitio et al. (2001) ${ }^{[16]}$ reported $1.1 \mathrm{~mm}$ as the initial size of zoea larva and the megalopa limit at $6.6 \mathrm{~mm}$. 


\section{CONCLUSION}

The research on behavior and feeding response of zoea larvae of recently quoted mud crab (Potamon ebonyicum) revealed that they could be transported in water for a long distance with significant rate of mortality. Transportation of zoea larvae in dry container might reduce colony formation and cannibalism to significant level. Judging from the results of the experiments, the larvae could be acclimatized to captivity within 7 days. Acclimatization of seed stock from the zoea stage could be an advantage in aquaculture as they might not struggle to escape at crab stage. Cannibalism might pose a threat to initial projects if that size should be considered as seed stock. Selection of larvae with suitable trait for high-density culture could be tried as a means of resolving the problem in subsequent investigation. Combined feed regime could be used in subsequent investigation to determine survival and growth potentials of the larvae in captivity.

\section{REFERENCES}

[1] Fisheries Fact Sheet., Mud crab. Fisheries Fact Sheet (28): www.fish.wa.gov.au.(2013)

[2] FAO, Mud crab aquaculture. A practical manual. FAO Technical Paper (567) 78 (2011).

[3] La Sara, Aguilar, R.O., Laureta, L.V., Baldevarona, R.B. and Ingles, J.A., The natural diet of the mud crab (Scylla serrata) in Lawele Bay Southeast Sulawesi, Indonesia. Philippine Agricultural Scientist 90 (1) Pp 6-14 (2007).

[4] Meynecke, J.O. and Richards, R.G., A full life cycle and spatially explicit individual-based model for the giant mud crab (Scylla serrata): a case study from a marine protected area. ICES Journal of Marine Science: 71(3) Pp 484-498 (2014).

[5] Akpaniteaku, R.C., A study on cultivability and feeding of mud crab (Potamon ebonyicum) in Ebonyi State, Nigeria. International Journal of Research and Advancement in Biosciences 3(2) Pp 133-135 (2013).

[6] Akpaniteaku, R.C., Mud crab survey and fecundity study around Ebonyi river basin, Ebonyi State, Nigeria. Global Journal of fisheries and Aquaculture 2(4) Pp165-168 (2014).

[7] Akpaniteaku, R.C., Aspects of reproduction and the condition of gravid mud crab (Crustaccea: Brachyura: Potamon) in Ebonyi State Nigeria. International Journal of Research Studies in Bioscience 3(1) Pp 104109 (2015).

[8] Akpaniteaku, R.C. and Onyemara, O.E., Growth and feed utilization in Potamon ebonyicum (Crustacea: Brachyura) fed domestic catfish feed in south east Nigeria. International Journal of fisheries and Aquatic Studies 4(6) Pp 394-396 (2016).

[9] SPC. Mud crab. http://www.SPC.int/aquculture/index.php.poption=com-commodities (2011).

[10] Anon., Mud crab culture: Different methods. Business ideas: Simple and easy business ideas for entrepreneur: www.bar.gov.ph (2013).

[11] Antharjanam, D., Crab culture. http://www.slideshare.net/DevikaAntharjanam.bluecrab.info/fullmoon. Htm. (2013)

[12] Blue Crab Archives., Moulting and the fullmoon. http://www.bluecrab.info/ fullmoon.htm. (Undated).

[13] Epelbaum, A. and Borisov, R., Feeding behavior and functional morphology of the reeding appendages of red king crab paralithodes can't schaticus larvae. Marune Biology Research 2(2) Pp 77-88 (2006).

[14] Baylon, J.C., Appropriate food type, feeding schedule and artemia density for zoea larva of the mud crab Scylla tranqueberica (crustacean: Decapoda: Potunidae). Aquaculture: 288 (3 \& 4) Pp 190-195 (2009).

[15] Anon., larval rearing of mud crabs. www.aquaculture.ugent.be/ service/news/2000.

[16] Quinitio, E.T., Parado-Estepa, F.D., Millamena, O.M., Rodriguez, E. and Borlonga, E., Seed production of mud crab Scylla serrata juveniles. Asian Fisheries Science (14) Pp (2001).

Citation: R. C. Akpaniteaku, "Acclimatization and Feeding of Zoea Larvae of Mud Crab Potamon Ebonyicum (Crustacea: Decapoda: Potamidae) in South-East Nigeria ", International Journal of Innovative Studies in Aquatic Biology and Fisheries, vol. 3, no. 3, p. 1-6, 2017. http://dx.doi.org/10.20431/2454-7670.0303001

Copyright: () 2017 Authors. This is an open-access article distributed under the terms of the Creative Commons Attribution License, which permits unrestricted use, distribution, and reproduction in any medium, provided the original author and source are credited. 